medRxiv preprint doi: https://doi.org/10.1101/2021.05.12.21257093; this version posted May 17, 2021. The copyright holder for this preprint

(which was not certified by peer review) is the author/funder, who has granted medRxiv a license to display the preprint in perpetuity.

All rights reserved. No reuse allowed without permission.

\title{
Clustered Mendelian Randomization analyses identifies distinct and opposing pathways in the causal association between insulin-like growth factor-1 and type 2 diabetes mellitus
}

\section{Wenyi Wang1, Ephrem Baraki Tesfay ${ }^{2}$, Ko Willems van Dijk ${ }^{1,3,4}$, Andrzej Bartke ${ }^{5}$, Diana van Heemst ${ }^{2}$, Raymond Noordam²}

1. Department of Human Genetics, Leiden University Medical Center, Leiden, the Netherlands; W.Wang1@lumc.nl (W.W); K.Willems_van_Dijk@lumc.nl (K.W.v.D)

2. Department of Internal Medicine, Section of Gerontology and Geriatrics; Leiden University Medical Center, Leiden, Netherlands; e.b.tesfay@gmail.com (E.B.T); R.Noordam@lumc.nl (R.N.); D.van_Heemst@lumc.nl (D.v.H.)

3. Department of Internal Medicine, Division Endocrinology, Leiden University Medical Center, Leiden, the Netherlands; K.Willems_van_Dijk@lumc.nl (K.W.v.D)

4. Leiden Laboratory for Experimental Vascular Medicine, Leiden University Medical

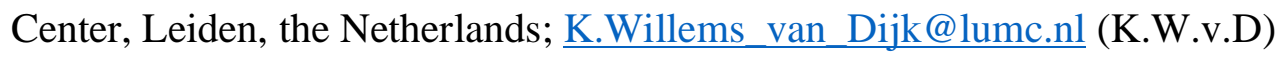

5. Department of Internal Medicine, Southern Illinois University School of Medicine, Springfield, Illinois, USA; abartke@ siumed.edu (A.B)

\section{Address of corresponding:}

Wenyi Wang MSc

Department of Human Genetics,

Leiden University Medical Center,

Leiden, the Netherlands

Email: w.wang1@lumc.nl 
medRxiv preprint doi: https://doi.org/10.1101/2021.05.12.21257093; this version posted May 17, 2021. The copyright holder for this preprint (which was not certified by peer review) is the author/funder, who has granted medRxiv a license to display the preprint in perpetuity.

All rights reserved. No reuse allowed without permission.

Word count (excluding abstract, research in context, references, acknowledgments, funding statement, authors' relationships and activities, contribution statement, tables and figure legends): 3556 
medRxiv preprint doi: https://doi.org/10.1101/2021.05.12.21257093; this version posted May 17, 2021. The copyright holder for this preprint

(which was not certified by peer review) is the author/funder, who has granted medRxiv a license to display the preprint in perpetuity.

\section{Abstract}

Aims/hypothesis: There is inconsistent evidence for the causal role of serum insulin-like growth factor-1 (IGF-1) concentration in the pathogenesis of type 2 diabetes. Here, we investigated the association between IGF-1 and type 2 diabetes using a combination of multivariable-adjusted and (clustered) Mendelian Randomization (MR) analyses in the UK Biobank.

Methods: We conducted Cox proportional hazard analyses in 451,232 European-ancestry individuals of the UK Biobank (55.3\% women, mean age at recruitment 56.6 years), among which 13,247 individuals developed type 2 diabetes during up to 12 years of follow-up. In addition, we conducted two-sample MR analyses based on independent SNPs associated with IGF-1. Given the heterogeneity between the causal estimates of individual instruments (Pvalue for Q statistic=4.03e-145), we also conducted clustered MR analyses. Biological pathway analyses of the identified clusters were performed by overrepresentation analyses. Results: In the Cox proportional hazard models, with IGF-1 concentrations stratified in quintiles, we observed that participants in the lowest quintile had the highest relative risk of type 2 diabetes (HR: 1.31; CI: 1.23-1.39). In contrast, in the two-sample MR analyses, higher genetically-influenced IGF-1 was associated with a higher risk of type 2 diabetes. Based on the heterogeneous distribution of causal effect estimates, six clusters associated either with a lower or a higher risk of type 2 diabetes were identified. The main clusters in which a higher IGF-1 was associated with a lower risk of type 2 diabetes consisted of instruments mapping to genes in the growth-hormone signaling pathway, whereas the main clusters in which a higher IGF-1 was associated with a higher risk of type 2 diabetes consisted of instruments mapping to genes in pathways related to amino acid metabolism and genomic integrity. Conclusion: The IGF-1 associated SNPs used as genetic instruments in MR analyses showed a heterogeneous distribution of causal effect estimates on the risk of type 2 diabetes. This was 
medRxiv preprint doi: https://doi.org/10.1101/2021.05.12.21257093; this version posted May 17, 2021. The copyright holder for this preprint (which was not certified by peer review) is the author/funder, who has granted medRxiv a license to display the preprint in perpetuity.

All rights reserved. No reuse allowed without permission.

likely explained by differences in the underlying molecular pathways that increase IGF-1 concentration and differentially mediate the effects of IGF-1 on type 2 diabetes.

Keywords: Clustered Mendelian randomization analysis; Cohort studies; Mendelian randomization analysis; type 2 diabetes; Insulin-like growth factor-1.

Abbreviations: BMI: body mass index; GWAS: genome-wide association analyses; GH: growth hormone; IGF-1: insulin-like growth factor-1; MR: Mendelian Randomization; SNPs: single nucleotide polymorphisms. 
medRxiv preprint doi: https://doi.org/10.1101/2021.05.12.21257093; this version posted May 17, 2021. The copyright holder for this preprint

(which was not certified by peer review) is the author/funder, who has granted medRxiv a license to display the preprint in perpetuity.

\section{Introduction}

Insulin-like growth factor-1 (IGF-1) is a pleiotropic hormone that plays a major role in cellular growth, proliferation and survival [1]. The secretion of IGF-1, predominately by the liver, is promoted by growth hormone $(\mathrm{GH})$ while conversely, IGF-1 in the circulation feeds back centrally to hypothalamus to inhibit GH secretion [2]. The availability of free IGF-1 in the blood is regulated by its association with distinct insulin-like growth factor binding proteins (IGFBPs) which can increase IGF-1 half-life or block its binding to IGF-1 receptors [3]. IGF-1 was found to be involved in the pathophysiology of various diseases, including cancer, neurodegenerative disease, cardiovascular disease, and type 2 diabetes mellitus [4]. Several (prospective) cohort studies have found that lower levels of IGF-1 were associated with an increased risk of impaired glucose tolerance, increased insulin resistance and hence the development of diabetes mellitus [5,6].

In contrast to these multivariable-adjusted association analyses, a recent study demonstrated that a higher genetically-influenced IGF-1 concentration was associated with a higher risk of developing type 2 diabetes using Mendelian Randomization (MR) analyses [7]. MR is an approach to determine whether the association between risk factors and outcome is causal by using genetic variants as instrumental variables [8]. However, in some circumstances, there is clear heterogeneity in the causal effects of the individual single nucleotide polymorphisms (SNPs) that are used as instrumental variables, which may indicate either pleiotropy or differences in biological pathways contributing to high levels of the exposure [9]. Clustered MR was recently developed to provide a means to address the heterogeneity in causal effects by clustering variants that show similar individual causal estimates on the outcome [9]. Previously, such context-dependent MR analyses have been proposed to provide more biological perspective in causal associations $[10,11]$. 
medRxiv preprint doi: https://doi.org/10.1101/2021.05.12.21257093; this version posted May 17, 2021. The copyright holder for this preprint (which was not certified by peer review) is the author/funder, who has granted medRxiv a license to display the preprint in perpetuity.

All rights reserved. No reuse allowed without permission.

We hypothesized that heterogeneity in causal effects of individual variants could be a reflection of different biological mechanisms involved in the association between IGF-1 and type 2 diabetes. For example, variation influenced by processes causing insufficient GH signaling may have a different impact on T2D than variation influenced by processes causing increased GH resistance. Therefore, in this study, we aimed to investigate the association between IGF-1 and incident type 2 diabetes followed by clustered MR analyses [9] in the large UK Biobank population, and explored the possible biological pathways involved in the clustered causal associations. 
medRxiv preprint doi: https://doi.org/10.1101/2021.05.12.21257093; this version posted May 17, 2021. The copyright holder for this preprint

(which was not certified by peer review) is the author/funder, who has granted medRxiv a license to display the preprint in perpetuity.

\section{Methods}

Study setting and study population

The UK Biobank is a very large prospective cohort study with over 500,000 participants aged 40-69 years at recruitment across the entire United Kingdom (UK) [12]. Participants were recruited between 2006 and 2010 in 22 assessment centers across the UK. Baseline examinations in all participants included physical measures, collection of blood, urine and saliva, a self-completed touch-screen questionnaire, and a brief computer-assisted interview to investigate sociodemographic, family history, environmental factors, lifestyle, psychosocial factors, etc. The UK Biobank study was approved by the North-West Multicenter Research Ethics Committee (MREC). Access to information to invite participants was approved by the Patient Information Advisory Group (PIAG) from England and Wales. All participants in the UK Biobank study provided written informed consent.

The present project was accepted under project number 22474. We restricted the analyses to the UK Biobank participants who reported to be of European ancestry including British, Irish and any other European background, who had information available on serum IGF-1 concentration, and who were in the full release imputed genomics datasets.

\section{Genotyping and genetic imputations}

Genome-wide genotype data for all 500,000 UK Biobank participants generated using Affymetrix UK BiLEVE Axiom array (initial 50,000 participants) and the Affymetrix UK Biobank Axiom Array (remaining 450,000 participants), which genotyped around 850,000 variants. All genetic data were quality controlled centrally by UK Biobank resources. In addition, UK Biobank resources performed centralized imputations on approximately 96 million genotypes using the UK10K haplotype [13], 1000 Genomes Phase 3 [14], and Haplotype Reference Consortium (HRC) reference panels [15]. Autosomal SNPs were prephased using SHAPEIT3 and imputed using IMPUTE4. Related individuals were identified 
medRxiv preprint doi: https://doi.org/10.1101/2021.05.12.21257093; this version posted May 17, 2021. The copyright holder for this preprint

(which was not certified by peer review) is the author/funder, who has granted medRxiv a license to display the preprint in perpetuity.

All rights reserved. No reuse allowed without permission.

by estimating kinship coefficients for all pairs of samples using only markers weakly informative of ancestral background. More information on the genotyping processes and genetic imputation can be found online

(https://biobank.ctsu.ox.ac.uk/crystal/label.cgi?id=263).

\section{Biochemical analyses}

Biological samples were collected to measure biochemical markers including IGF-1 at baseline (2006-2010) comprising 480,000 participant samples. Serum levels of IGF-1 were analyzed using chemiluminescent Immunoassay (DiaSorin Liaison XL) with a one-step sandwich. Coefficients of variation derived from the internal quality control samples of the low, medium, and high IGF-1 concentrations ranged from 6.03-6.18\%. More information on assay performance of the UK Biobank Biomarker Project can be found online (https://biobank.ctsu.ox.ac.uk/crystal/refer.cgi?id=1227).

\section{Outcome definitions}

Information on the diagnosis of type 2 diabetes during follow-up was obtained through linkage with the National Health System (NHS) medical records database. Diagnoses were mainly derived from hospital admissions data. More information related to the diagnosis of type 2 diabetes can be found on the websites of UK Biobank under data-field 130708 (https://biobank.ctsu.ox.ac.uk/crystal/field.cgi?id=130708).

Prospective analyses

Participants without diabetes mellitus at baseline were followed until the occurrence of type 2 diabetes, mortality or loss of follow-up, whichever occurred first. The association between IGF-1 levels and incidence of type 2 diabetes in the UK Biobank cohort was 
medRxiv preprint doi: https://doi.org/10.1101/2021.05.12.21257093; this version posted May 17, 2021. The copyright holder for this preprint

(which was not certified by peer review) is the author/funder, who has granted medRxiv a license to display the preprint in perpetuity.

All rights reserved. No reuse allowed without permission.

assessed using Cox proportional hazard models. Participants were categorized into five groups based on quintiles of IGF-1 concentration. Quintile 1 (lowest 20\%) and quintile 5 (highest 20\%) were used separately as reference groups to calculate the hazard ratio (HR), respectively. Potential confounders included sex, age at recruitment and baseline body mass index (BMI) based on height and weight measured at the assessment centers. The analyses were conducted in $\mathrm{R}$ using the survival package (version 3.2-7) [16]. The Kaplan Meier curve was plotted to visualize the difference of survival probability between IGF-1 quintiles and whether the proportionality assumption holds.

Genome-wide association analyses

Genome-wide association analyses (GWAS) on continuous IGF-1 concentrations and dichotomized IGF-1 blood levels (lowest 20\% versus remaining $80 \%$ and highest $20 \%$ versus remaining $80 \%$ ) were performed to provide a list of independent lead SNPs to be used as instrumental variables in the MR analyses. Analyses were performed using linear mixed models implemented in the program BOLT_LMM (version 2.3.2) [17]. We adjusted the analyses for age, sex and the first 10 principal components, and corrected for the Kinship matrix to correct for familial relationships in the UK Biobank population. Analyses were done on the autosomal chromosomes only. SNPs with a minor allele frequency $<0.01$ as well as SNPs with an imputation quality $<0.3$ were excluded. P-values of SNPs smaller than $5 \mathrm{e}^{-8}$ were extracted and stored for the MR analyses. Visualization of the results was performed using the R-based packages ggplot2 [18] and EasyStrata [19] (www.genepiregensburg.de/easystrata).

\section{Mendelian randomization analyses}

Two-sample MR was performed with summary-based statistics of GWAS using the R-based statistical package Two Sample MR (available at: 
medRxiv preprint doi: https://doi.org/10.1101/2021.05.12.21257093; this version posted May 17, 2021. The copyright holder for this preprint

(which was not certified by peer review) is the author/funder, who has granted medRxiv a license to display the preprint in perpetuity.

http://github.com/MRCIEU/TwoSampleMR) [20]. This statistical package also connects to a large library of exposures from published GWAS to use as instrumental variables, which is aligned with the online GWAS catalogue.

For the present study, we performed the clumping process (window size $=10,000 \mathrm{~kb}$, $\left.\mathrm{R}^{2}<0.001\right)$ with the European samples from the 1000 genomes project which were used to estimate linkage disequilibrium (LD) between SNPs. Among those pairs of SNPs with $\mathrm{R}^{2}$ above the specified threshold $\left(\mathrm{R}^{2}=0.001\right)$, only the SNPs with the lowest P-value were retained to provide a list of independent lead SNPs from the MR analyses. Otherwise, the statistical power of MR analyses would be overestimated (e.g., underestimated standard errors of the summary estimates of the MR analyses). SNPs present in UK Biobank, but absent from the LD reference panel, were removed. On the basis of the significant independent lead SNPs (P-value $<5 \mathrm{e}-8)$, we assessed their possible causal association with type 2 diabetes. For this analysis, we used publicly-available summary-statistics GWAS meta-analysis from 32 studies on 898,130 individuals (74,124 type 2 diabetes cases and 824,006 controls) of European ancestry [21].

Methods for MR analyses of summary-level data based on a two-sample design have been described in detail previously $[22,23]$. Using inverse-variance-weighted (IVW) analyses, we combined the effects of the individual genetic instruments to obtain a genetically-determined association between exposure and outcome under the assumption of the absence of horizontal pleiotropy. However, given the large number of genetic instruments included in the present analyses, there is a high probability that at least some SNPs show pleiotropic effect. To test whether possible pleiotropic effects could bias the overall effect estimates (horizontal pleiotropy), we performed the sensitivity analyses MR Egger regression [24] and weighted median estimator (WME) analyses [25]. MR Egger does not force the regression line through the intercept and is, therefore, able to test for the presence of 
medRxiv preprint doi: https://doi.org/10.1101/2021.05.12.21257093; this version posted May 17, 2021. The copyright holder for this preprint

(which was not certified by peer review) is the author/funder, who has granted medRxiv a license to display the preprint in perpetuity.

directional pleiotropy, and WME estimator assumes at least $50 \%$ of the instruments included in the MR analyses were valid.

\section{Clustered Mendelian randomization analyses}

Clustered MR analyses were conducted to identify groups of genetic variants that have similar causal estimates of the exposure on the outcome. If the causal estimates of each genetic variant on the outcome were similar (e.g., their ratio-estimates were similar in direction, magnitude and precision), it was divided into different clusters in which the included genetic variants were more homogeneous concerning the causal estimates [9]. The inclusion probability of SNPs in each cluster was higher than 0.8 .

In order to identify distinct causal effects of genetic variants derived from GWAS of continuous IGF-1 levels on type 2 diabetes, we made use of the R-based MR-Clust package (https://github.com/cnfoley/mrclust). MR-Clust performs likelihood-based clustering on Wald ratio-estimates and accompanied standard errors. Genetic instruments within a cluster share similar causal estimates (e.g., Wald ratio-estimates are similar in direction, magnitude and precision) of the causal effect of the exposure on the outcome. MR analyses were repeated on all clusters to investigate the causal effects of each cluster on type 2 diabetes.

\section{Pathway analyses}

Based on the instruments that were part of a certain cluster, we performed pathway analyses to provide insights into biological pathways which could explain the heterogeneity between causal estimates of genetic variants in different clusters on type 2 diabetes. Genetic variants in each cluster were extracted and processed using the online tool FUMA to perform gene mapping where independent lead SNPs were determined at $\mathrm{R}^{2}<0.1$ using the 1000 Genome Project Phase 3 as a reference panel population $[14,26]$. Based on derived genes, pathway analyses were conducted by using GENE2FUNC in the online tool FUMA, which is able to 
medRxiv preprint doi: https://doi.org/10.1101/2021.05.12.21257093; this version posted May 17, 2021. The copyright holder for this preprint (which was not certified by peer review) is the author/funder, who has granted medRxiv a license to display the preprint in perpetuity.

All rights reserved. No reuse allowed without permission.

check pathways coded by related genetic variants [27]. The GENE2FUNC connects to massive pathway databases by using overrepresentation enrichment tests, among which KEGG and Reactome databases were used in the pathway analyses. More information can be found on the website of FUMA (https://fuma.ctglab.nl/) 
medRxiv preprint doi: https://doi.org/10.1101/2021.05.12.21257093; this version posted May 17, 2021. The copyright holder for this preprint

(which was not certified by peer review) is the author/funder, who has granted medRxiv a license to display the preprint in perpetuity.

\section{Results}

Characteristics of the study population

In total, 451,232 European participants without diabetes mellitus at baseline were included in our study of whom 13,247 developed type 2 diabetes in up to 12 years of followup (Table 1). Of the participants not developing type 2 diabetes, $55.7 \%$ were women, the mean age at recruitment was $56.5(\mathrm{SD}=8.1)$ years, the average $\mathrm{BMI}$ was $27.1(\mathrm{SD}=4.5) \mathrm{kg} / \mathrm{m}^{2}$ and the mean IGF-1 levels were $21.5(\mathrm{SD}=5.6) \mathrm{nmol} / \mathrm{L}$. Of the participants developing type 2 diabetes during follow-up, women accounted for $41.9 \%$, the mean age at recruitment was $59.3(\mathrm{SD}=7.2)$ years, the average BMI was $31.7(\mathrm{SD}=5.6) \mathrm{kg} / \mathrm{m}^{2}$ and the mean IGF-1 level was $19.9(\mathrm{SD}=6.5) \mathrm{nmol} / \mathrm{L}$.

\section{Prospective analyses}

Multivariable-adjusted Cox proportional hazard model analyses were performed to evaluate the association between quintiles of IGF-1 levels and incident type 2 diabetes. Kaplan Meier curve (Figure 1) illustrated that participants in the lower IGF-1 quintiles (quintile 1and 2) had proportionally lower risk of type 2 diabetes compared to participants in the higher quintiles (quintile 3, 4 and 5).

More specifically, individuals in quintile 2 had a lower risk of type 2 diabetes (HR: 0.77; CI: 0.73-0.81) than individuals in quintile 1 (Table 2), as did those in quintile 3 (HR: 0.70; CI: 0.66-0.74), quintile 4 (HR: 0.68; CI: 0.64-0.72) and quintile 5 (HR: 0.76; CI: 0.720.81). Taking participants in quintile 5 as the reference group, a higher risk was observed in quintile 1 (HR: 1.31; CI: 1.23-1.39), and those in quintile 3 (HR: 0.92; CI: 0.86-0.98) and 4 (HR: 0.89; CI: 0.83-0.95) had a lower risk of developing type 2 diabetes. 
medRxiv preprint doi: https://doi.org/10.1101/2021.05.12.21257093; this version posted May 17, 2021. The copyright holder for this preprint

(which was not certified by peer review) is the author/funder, who has granted medRxiv a license to display the preprint in perpetuity.

Mendelian Randomization analyses

There were 95,877 significant SNPs $(\mathrm{P}<5 \mathrm{e}-8)$ identified in the GWAS of continuous IGF-1 (Supplementary Figure 1) of which we derived 387 independent lead SNPs to be used in the MR analyses. The MR estimates of assessing the causal effect of IGF-1 on type 2 diabetes showed that a $1 \mathrm{nmol} / \mathrm{L}$ increase in IGF-1 was associated with a $1 \%$ higher risk of type 2 diabetes in the IVW analyses (OR: 1.01; CI: 1.00-1.02). Similar results were obtained from MR Egger (OR: 1.02; CI: 1.00-1.05) and WME analyses (OR: 1.01; CI: 1.00-1.02).

The GWAS on dichotomized IGF-1 for lowest or highest $20 \%$ versus the remaining 80\% resulted in 154 and 184 independent lead SNPs, respectively. MR analyses showed that low IGF-1 was associated with a lower risk of type 2 diabetes in the IVW analyses (OR: 0.70; CI: 0.53-0.94) and high IGF-1 was associated with a higher risk of type 2 diabetes in the IVW analyses (OR: 1.66; CI: 1.28-2.15) (Supplementary Table 1, Supplementary Table 2; Supplementary Figure 2). Results remained similar in the MR-Egger and WME analyses.

\section{Clustered Mendelian randomization analyses}

We observed large heterogeneity in the individual causal estimates (Figure 2) as was also evidenced by the $\mathrm{Q}$ statistic $\left(\mathrm{P}=4.03 \mathrm{e}^{-145}\right)$. The individual causal estimates were clustered into a total of 6 clusters with an inclusion probability of SNPs higher than 0.8 (Figure 3). MR estimates from different methods of assessing the causal effect of 6 clusters on type 2 diabetes are presented in Table 3 and Supplementary Figure 3. In cluster 1 (IVW: OR:1.54, CI:1.43-1.65), cluster 2 (IVW: OR:1.03, CI:1.02-1.04) and cluster 5 (IVW: OR:1.20, CI:1.181.22), higher levels of IGF-1 level were associated with a higher risk of type 2 diabetes. On the other hand, cluster 3 (IVW: OR:0.92, CI:0.91-0.94), cluster 4 (IVW: OR:0.62, CI:0.580.67 ) and cluster 6 (IVW: OR:0.80, CI:0.76-0.85) showed that higher levels of IGF-1 were associated with lower risk of type 2 diabetes. The results from sensitivity analyses by using 
medRxiv preprint doi: https://doi.org/10.1101/2021.05.12.21257093; this version posted May 17, 2021. The copyright holder for this preprint

(which was not certified by peer review) is the author/funder, who has granted medRxiv a license to display the preprint in perpetuity.

All rights reserved. No reuse allowed without permission.

weighted median estimator and MR-Egger did not materially differ from the result of the IWV method.

Pathway analyses

After mapping the SNPs to genes, an overrepresentation analysis was performed using the KEGG and Reactome databases. We found that cluster 2, cluster 3 and cluster 4 mapped to specific pathways. Cluster 2 mapped to pathways related to systemic lupus erythematosus, metabolism of xenobiotics by cytochrome P450 and DNA/molecular integrity pathways (Supplementary Figure 4). Cluster 3 mapped to the pathways related to Janus kinase/signal transducers and activators of transcription (JAK/SAT), prolactin receptor signaling and GH receptor signaling (Supplementary Figure 5). Cluster 4 mapped to the pathways related to glycine, serine and threonine metabolism, choline catabolism and sulfur amino acid metabolism (Supplementary Figure 6). Clusters 1, 5 and 6 did not map to any specific pathway. 
medRxiv preprint doi: https://doi.org/10.1101/2021.05.12.21257093; this version posted May 17, 2021. The copyright holder for this preprint

(which was not certified by peer review) is the author/funder, who has granted medRxiv a license to display the preprint in perpetuity.

\section{Discussion and conclusion}

In this study, we investigated the association of IGF-1 and type 2 diabetes using prospective multivariable-adjusted survival analyses followed by MR and clustered MR analyses in the UK Biobank. The results from the MR analyses showed that a geneticallyinfluenced higher level of IGF-1 was associated with a higher risk of type 2 diabetes, which was in contrast to the result from the prospective analyses showing that a higher concentration of IGF-1 was associated with a lower risk of type 2 diabetes. Since the underlying individual genetic instruments showed a heterogeneous distribution of causal effect estimates, clustered MR identified 6 clusters of genetic instruments for IGF-1 with different associations with type 2 diabetes, which mapped to distinct molecular pathways. Collectively, our results indicate that the association between IGF-1 and the risk of developing type 2 diabetes is context-dependent.

Findings from other prospective studies regarding the association between IGF-1 and type 2 diabetes have been inconsistent. Our results from the prospective analyses were in line with another cohort study showing high levels of IGF-1 were associated with a lower risk of type 2 diabetes mellitus risk during 4.5 years of follow-up [5]. However, some nested casecohort studies suggested there was no association between total IGF-1 levels and the risk of type 2 diabetes [28, 29]. In addition, a cohort study found that the association between free IGF-1 and type 2 diabetes was dependent on the level of insulin in women [30]. The inconsistency of these findings reinforces the notion that the association between IGF-1 and type 2 diabetes is context-dependent which is in line with the distinct biological mechanisms identified by the clustered MR analyses in our study.

Many studies found a J- or U- shaped association between IGF-1 and type 2 diabetes $[5,31]$ or insulin resistance [32]. For example, one study showed that individuals with both low- or high- IGF-1 levels were at increased risk of developing diabetes in a prospective 
medRxiv preprint doi: https://doi.org/10.1101/2021.05.12.21257093; this version posted May 17, 2021. The copyright holder for this preprint

(which was not certified by peer review) is the author/funder, who has granted medRxiv a license to display the preprint in perpetuity.

cohort study [31]. Similarly, a U-shaped association between IGF-1 and measures of insulin resistance was found in a cross-sectional study in Danish adults [32]. Partly in line with these results, we observed a J-shaped relationship between IGF-1 and type 2 diabetes with particularly low levels of IGF-1 to be associated with an increased risk of developing type 2 diabetes. However, in the MR analyses of highest/lowest $20 \%$ IGF-1 and type 2 diabetes, we did not find indications that the association between genetically-influenced IGF-1 levels and type 2 diabetes was non-linear, as can be specifically observed in MR analyses in continuous IGF-1 where genetically-influenced low IGF-1 was associated with a lower risk of T2D and where genetically-influenced high IGF-1 was associated with a higher risk of T2D; effect sizes were similar from these analyses, but in opposite direction.

The result of MR analyses of continuous IGF-1 and type 2 diabetes in our study was supported by a recent publication showing higher levels of IGF-1 were causally associated with increased risk of developing type 2 diabetes [7]. However, we observed large betweenSNP heterogeneity, and the causal estimates were not proportional to each other. We identified 6 main clusters of IGF-1 genetic instruments with distinct effects on type 2 diabetes by using clustered MR. After mapping the genetic instruments to genes and overrepresentation analysis using the KEGG and Reactome databases, several clusters were mapped to specific pathways.

Cluster 2 (in which higher genetically-influenced IGF-1 was associated with a higher risk of type 2 diabetes) mapped to multiple pathways all related to DNA/molecular integrity pathways. The association between the GH/IGF-1 axis and DNA damage and aging has long been observed [33]. For example, low IGF-1 expression was observed in the rrccl $^{-/-}$mouse model, which also exhibits accelerated aging due to a genetic defect in DNA repair [34]. It has also been reported that developmental GH/IGF-1 deficiency is associated with increased cellular DNA repair capacity and upregulation of DNA repair-related genes [35]. These latter 
medRxiv preprint doi: https://doi.org/10.1101/2021.05.12.21257093; this version posted May 17, 2021. The copyright holder for this preprint

(which was not certified by peer review) is the author/funder, who has granted medRxiv a license to display the preprint in perpetuity.

observations are consistent with genetically influenced and thus life-long higher IGF-1 levels and decreased DNA repair capacity. The association between the DNA damage response and type 2 diabetes is well described, yet poorly understood [36].

Cluster 3 (in which higher levels of genetically-influenced IGF-1 was associated with a lower risk of type 2 diabetes) was mapped to pathways related to $\mathrm{GH}$ receptor signaling. Dysregulation of GH receptor signaling and the GH-IGF-1 axis can lead to multiple diseases such as type 2 diabetes $[37,38]$. Mice with liver IGF-1 deficiency had a fourfold increase in GH levels. Upon treatment with a GH antagonist these mice had decreased blood glucose and insulin levels and increased peripheral insulin sensitivity compared with mice with liver IGF1 deficiency. These data indicate that the GH/IGF-1 axis plays a balancing role in insulin sensitivity and thus type 2 diabetes [39]. In addition, an epidemiological cross-sectional study showed that IGF-1 was associated with type 2 diabetes risk, but this association varied depending on the insulin levels: in individuals with low levels of insulin IGF-1 decreased type 2 diabetes risk and in individuals with high levels of insulin it increased type 2 diabetes risk [30].

Cluster 4 (in which high genetically-influenced IGF-1 levels were associated with a lower risk of type 2 diabetes) was mapped to pathways related to the metabolism of amino acids. Branched-chain amino acids have been associated with a higher risk of type 2 diabetes in several prospective studies [40, 41]. In addition, IGF-1 was able to affect protein metabolism by activating the mechanistic target of rapamycin (mTOR) pathway through phosphoinositide 3-kinase (PI3K) [42]. It was also found that muscle protein turnover was regulated by IGF-1 signaling via suppression of FoxO-regulated, autophagy-mediated protein degradation [43].

The main strength of our study is the extremely large sample size allowing stratification of the genetic instruments with ample statistical power. One limitation of the 
medRxiv preprint doi: https://doi.org/10.1101/2021.05.12.21257093; this version posted May 17, 2021. The copyright holder for this preprint (which was not certified by peer review) is the author/funder, who has granted medRxiv a license to display the preprint in perpetuity.

All rights reserved. No reuse allowed without permission.

present study is that the IGF-1 level used was total IGF-1 concentration and not free IGF-1 (e.g., relative to the concentration of IGF binding proteins). Furthermore, the study was performed in a study of European-ancestry participants. Translation of the results to participants of non-European ancestry should be done with caution.

In conclusion, we found that a higher level of IGF-1 was causally associated with both a higher and a lower risk of development of type 2 diabetes and these inverse associations seem to be regulated by distinct biological mechanisms. Therefore, the total concentration of IGF-1 does not provide insight into the risk of developing type 2 diabetes. 
medRxiv preprint doi: https://doi.org/10.1101/2021.05.12.21257093; this version posted May 17, 2021. The copyright holder for this preprint

(which was not certified by peer review) is the author/funder, who has granted medRxiv a license to display the preprint in perpetuity.

All rights reserved. No reuse allowed without permission.

\section{Declarations}

Data availability: Data that support the findings of this study have been deposited in the UK

Biobank under project number 22474. Data is available on request after approval of a research proposal by UK Biobank resources.

\section{Funding}

This work was supported by the American Diabetes Association grant \#1-19-IBS-126. Wenyi

Wang MSc was supported with a scholarship from the China Scholarship Council (201907720011).

Conflicts of interest: The authors declare to have no conflict of interest.

Author Contributions:

WW, EBT. KWvD, AB, DvH, RN: Substantial contributions to conception, design, acquisition of data, analyses and data interpretation; Drafting article and critically comment on the initial versions of the manuscript; Final approval of the manuscript before submission. 
medRxiv preprint doi: https://doi.org/10.1101/2021.05.12.21257093; this version posted May 17, 2021. The copyright holder for this preprint

(which was not certified by peer review) is the author/funder, who has granted medRxiv a license to display the preprint in perpetuity.

All rights reserved. No reuse allowed without permission.

\section{Reference}

[1] Rajpathak SN, Gunter MJ, Wylie-Rosett J, et al. (2009) The role of insulin-like growth factor-I and its binding proteins in glucose homeostasis and type 2 diabetes.

Diabetes/Metabolism Research and Reviews 25(1): 3-12. https://doi.org/10.1002/dmrr.919

[2] Nicholls AR, Holt RI (2016) Growth Hormone and Insulin-Like Growth Factor-1.

Front Horm Res 47: 101-114. 10.1159/000445173

[3] Aguirre GA, De Ita JR, de la Garza RG, Castilla-Cortazar I (2016) Insulin-like growth factor-1 deficiency and metabolic syndrome. J Transl Med 14: 3-3. 10.1186/s12967-015$0762-\mathrm{z}$

[4] Rosenzweig SA (2020) The Continuing Evolution of Insulin-like Growth Factor Signaling. F1000Res 9: F1000 Faculty Rev-1205. 10.12688/f1000research.22198.1

[5] Sandhu MS, Heald AH, Gibson JM, Cruickshank JK, Dunger DB, Wareham NJ (2002) Circulating concentrations of insulin-like growth factor-I and development of glucose intolerance: a prospective observational study. Lancet 359(9319): 1740-1745. 10.1016/s01406736(02)08655-5

[6] Rajpathak SN, McGinn AP, Strickler HD, et al. (2008) Insulin-like growth factor(IGF)-axis, inflammation, and glucose intolerance among older adults. Growth Horm IGF Res 18(2): 166-173. 10.1016/j.ghir.2007.08.004

[7] Larsson SC, Michaëlsson K, Burgess S (2020) IGF-1 and cardiometabolic diseases: a Mendelian randomisation study. Diabetologia. 10.1007/s00125-020-05190-9

[8] Emdin CA, Khera AV, Kathiresan S (2017) Mendelian Randomization. JAMA 318(19): 1925-1926. 10.1001/jama.2017.17219

[9] Foley CN, Mason AM, Kirk PDW, Burgess S (2020) MR-Clust: Clustering of genetic variants in Mendelian randomization with similar causal estimates. Bioinformatics. 10.1093/bioinformatics/btaa778 
medRxiv preprint doi: https://doi.org/10.1101/2021.05.12.21257093; this version posted May 17, 2021. The copyright holder for this preprint

(which was not certified by peer review) is the author/funder, who has granted medRxiv a license to display the preprint in perpetuity.

All rights reserved. No reuse allowed without permission.

[10] Noordam R, Oudt CH, Bos MM, Smit RAJ, van Heemst D (2018) High-sensitivity Creactive protein, low-grade systemic inflammation and type 2 diabetes mellitus: A twosample Mendelian randomization study. Nutr Metab Cardiovasc Dis 28(8): 795-802. 10.1016/j.numecd.2018.03.008

[11] Verkouter I, de Mutsert R, Smit RAJ, et al. (2020) The contribution of tissue-grouped BMI-associated gene sets to cardiometabolic-disease risk: a Mendelian randomization study. International journal of epidemiology 49(4): 1246-1256. 10.1093/ije/dyaa070

[12] Sudlow C, Gallacher J, Allen N, et al. (2015) UK biobank: an open access resource for identifying the causes of a wide range of complex diseases of middle and old age. PLoS Med 12(3): e1001779. 10.1371/journal.pmed.1001779

[13] Walter K, Min JL, Huang J, et al. (2015) The UK10K project identifies rare variants in health and disease. Nature 526(7571): 82-90. 10.1038/nature14962

[14] Auton A, Brooks LD, Durbin RM, et al. (2015) A global reference for human genetic variation. Nature 526(7571): 68-74. 10.1038/nature15393

[15] McCarthy S, Das S, Kretzschmar W, et al. (2016) A reference panel of 64,976 haplotypes for genotype imputation. Nat Genet 48(10): 1279-1283. 10.1038/ng.3643

[16] Therneau TM (2020) A Package for Survival Analysis in R. Available from https://CRAN.R-project.org/package=survival

[17] Loh PR, Tucker G, Bulik-Sullivan BK, et al. (2015) Efficient Bayesian mixed-model analysis increases association power in large cohorts. Nat Genet 47(3): 284-290.

10.1038/ng.3190

[18] Wickham H (2016) ggplot2: Elegant Graphics for Data Analysis. Springer-Verlag New York 
medRxiv preprint doi: https://doi.org/10.1101/2021.05.12.21257093; this version posted May 17, 2021. The copyright holder for this preprint

(which was not certified by peer review) is the author/funder, who has granted medRxiv a license to display the preprint in perpetuity.

All rights reserved. No reuse allowed without permission.

[19] Winkler TW, Kutalik Z, Gorski M, Lottaz C, Kronenberg F, Heid IM (2015)

EasyStrata: evaluation and visualization of stratified genome-wide association meta-analysis data. Bioinformatics (Oxford, England) 31(2): 259-261. 10.1093/bioinformatics/btu621

[20] Hemani G, Zheng J, Elsworth B, et al. (2018) The MR-Base platform supports systematic causal inference across the human phenome. Elife 7. 10.7554/eLife.34408

[21] Mahajan A, Taliun D, Thurner M, et al. (2018) Fine-mapping type 2 diabetes loci to single-variant resolution using high-density imputation and islet-specific epigenome maps. Nat Genet 50(11): 1505-1513. 10.1038/s41588-018-0241-6

[22] Burgess S, Scott RA, Timpson NJ, Davey Smith G, Thompson SG (2015) Using published data in Mendelian randomization: a blueprint for efficient identification of causal risk factors. Eur J Epidemiol 30(7): 543-552. 10.1007/s10654-015-0011-z

[23] Noordam R, Smit RA, Postmus I, Trompet S, van Heemst D (2016) Assessment of causality between serum gamma-glutamyltransferase and type 2 diabetes mellitus using publicly available data: a Mendelian randomization study. Int J Epidemiol 45(6): 1953-1960. 10.1093/ije/dyw306

[24] Bowden J, Davey Smith G, Burgess S (2015) Mendelian randomization with invalid instruments: effect estimation and bias detection through Egger regression. International Journal of Epidemiology 44(2): 512-525. 10.1093/ije/dyv080

[25] Bowden J, Davey Smith G, Haycock PC, Burgess S (2016) Consistent Estimation in Mendelian Randomization with Some Invalid Instruments Using a Weighted Median Estimator. Genet Epidemiol 40(4): 304-314. 10.1002/gepi.21965

[26] Watanabe K, Taskesen E, van Bochoven A, Posthuma D (2017) Functional mapping and annotation of genetic associations with FUMA. Nature Communications 8(1): 1826. 10.1038/s41467-017-01261-5 
medRxiv preprint doi: https://doi.org/10.1101/2021.05.12.21257093; this version posted May 17, 2021. The copyright holder for this preprint

(which was not certified by peer review) is the author/funder, who has granted medRxiv a license to display the preprint in perpetuity.

All rights reserved. No reuse allowed without permission.

[27] Watanabe K, Umićević Mirkov M, de Leeuw CA, van den Heuvel MP, Posthuma D (2019) Genetic mapping of cell type specificity for complex traits. Nature Communications 10(1): 3222. 10.1038/s41467-019-11181-1

[28] Drogan D, Schulze MB, Boeing H, Pischon T (2016) Insulin-Like Growth Factor 1 and Insulin-Like Growth Factor-Binding Protein 3 in Relation to the Risk of Type 2 Diabetes Mellitus: Results From the EPIC-Potsdam Study. American Journal of Epidemiology 183(6): 553-560. 10.1093/aje/kwv188

[29] Similä ME, Kontto JP, Virtamo J, et al. (2019) Insulin-like growth factor I, binding proteins -1 and -3 , risk of type 2 diabetes and macronutrient intakes in men. British Journal of Nutrition 121(8): 938-944. 10.1017/S0007114519000321

[30] Rajpathak SN, He M, Sun Q, et al. (2012) Insulin-Like Growth Factor Axis and Risk of Type 2 Diabetes in Women. Diabetes 61(9): 2248-2254. 10.2337/db11-1488

[31] Schneider HJ, Friedrich N, Klotsche J, et al. (2011) Prediction of incident diabetes mellitus by baseline IGF1 levels. Eur J Endocrinol 164(2): 223-229. 10.1530/eje-10-0963 [32] Friedrich N, Thuesen B, Jørgensen T, et al. (2012) The association between IGF-I and insulin resistance: a general population study in Danish adults. Diabetes care 35(4): 768-773. $10.2337 / \mathrm{dc} 11-1833$

[33] Hinkal G, Donehower LA (2008) How does suppression of IGF-1 signaling by DNA damage affect aging and longevity? Mech Ageing Dev 129(5): 243-253. 10.1016/j.mad.2008.02.005

[34] Niedernhofer LJ, Garinis GA, Raams A, et al. (2006) A new progeroid syndrome reveals that genotoxic stress suppresses the somatotroph axis. Nature 444(7122): 1038-1043. 10.1038/nature05456

[35] Podlutsky A, Valcarcel-Ares MN, Yancey K, et al. (2017) The GH/IGF-1 axis in a critical period early in life determines cellular DNA repair capacity by altering transcriptional 
medRxiv preprint doi: https://doi.org/10.1101/2021.05.12.21257093; this version posted May 17, 2021. The copyright holder for this preprint

(which was not certified by peer review) is the author/funder, who has granted medRxiv a license to display the preprint in perpetuity.

All rights reserved. No reuse allowed without permission.

regulation of DNA repair-related genes: implications for the developmental origins of cancer.

GeroScience 39(2): 147-160. 10.1007/s11357-017-9966-X

[36] Shimizu I, Yoshida Y, Suda M, Minamino T (2014) DNA Damage Response and

Metabolic Disease. Cell Metabolism 20(6): 967-977.

https://doi.org/10.1016/j.cmet.2014.10.008

[37] Aguirre GA, De Ita JR, de la Garza RG, Castilla-Cortazar I (2016) Insulin-like growth factor-1 deficiency and metabolic syndrome. J Transl Med 14(1): 3. 10.1186/s12967-015-

$0762-\mathrm{z}$

[38] Guevara-Aguirre J, Guevara A, Palacios I, Pérez M, Prócel P, Terán E (2018) GH and

GHR signaling in human disease. Growth Horm IGF Res 38: 34-38.

https://doi.org/10.1016/j.ghir.2017.12.006

[39] Yakar S, Setser J, Zhao H, et al. (2004) Inhibition of growth hormone action improves insulin sensitivity in liver IGF-1-deficient mice. J Clin Invest 113(1): 96-105.

10.1172/JCI17763

[40] Tillin T, Hughes AD, Wang Q, et al. (2015) Diabetes risk and amino acid profiles: cross-sectional and prospective analyses of ethnicity, amino acids and diabetes in a South Asian and European cohort from the SABRE (Southall And Brent REvisited) Study.

Diabetologia 58(5): 968-979. 10.1007/s00125-015-3517-8

[41] Floegel A, Stefan N, Yu Z, et al. (2013) Identification of serum metabolites associated with risk of type 2 diabetes using a targeted metabolomic approach. Diabetes 62(2): 639-648. $10.2337 / \mathrm{db} 12-0495$

[42] Feng Z, Levine AJ (2010) The regulation of energy metabolism and the IGF-1/mTOR pathways by the p53 protein. Trends Cell Biol 20(7): 427-434. 10.1016/j.tcb.2010.03.004 
medRxiv preprint doi: https://doi.org/10.1101/2021.05.12.21257093; this version posted May 17, 2021. The copyright holder for this preprint (which was not certified by peer review) is the author/funder, who has granted medRxiv a license to display the preprint in perpetuity.

All rights reserved. No reuse allowed without permission.

[43] O’Neill BT, Lee KY, Klaus K, et al. (2016) Insulin and IGF-1 receptors regulate

FoxO-mediated signaling in muscle proteostasis. J Clin Invest 126(9): 3433-3446.

10.1172/JCI86522 
medRxiv preprint doi: https://doi.org/10.1101/2021.05.12.21257093; this version posted May 17, 2021. The copyright holder for this preprint (which was not certified by peer review) is the author/funder, who has granted medRxiv a license to display the preprint in perpetuity.

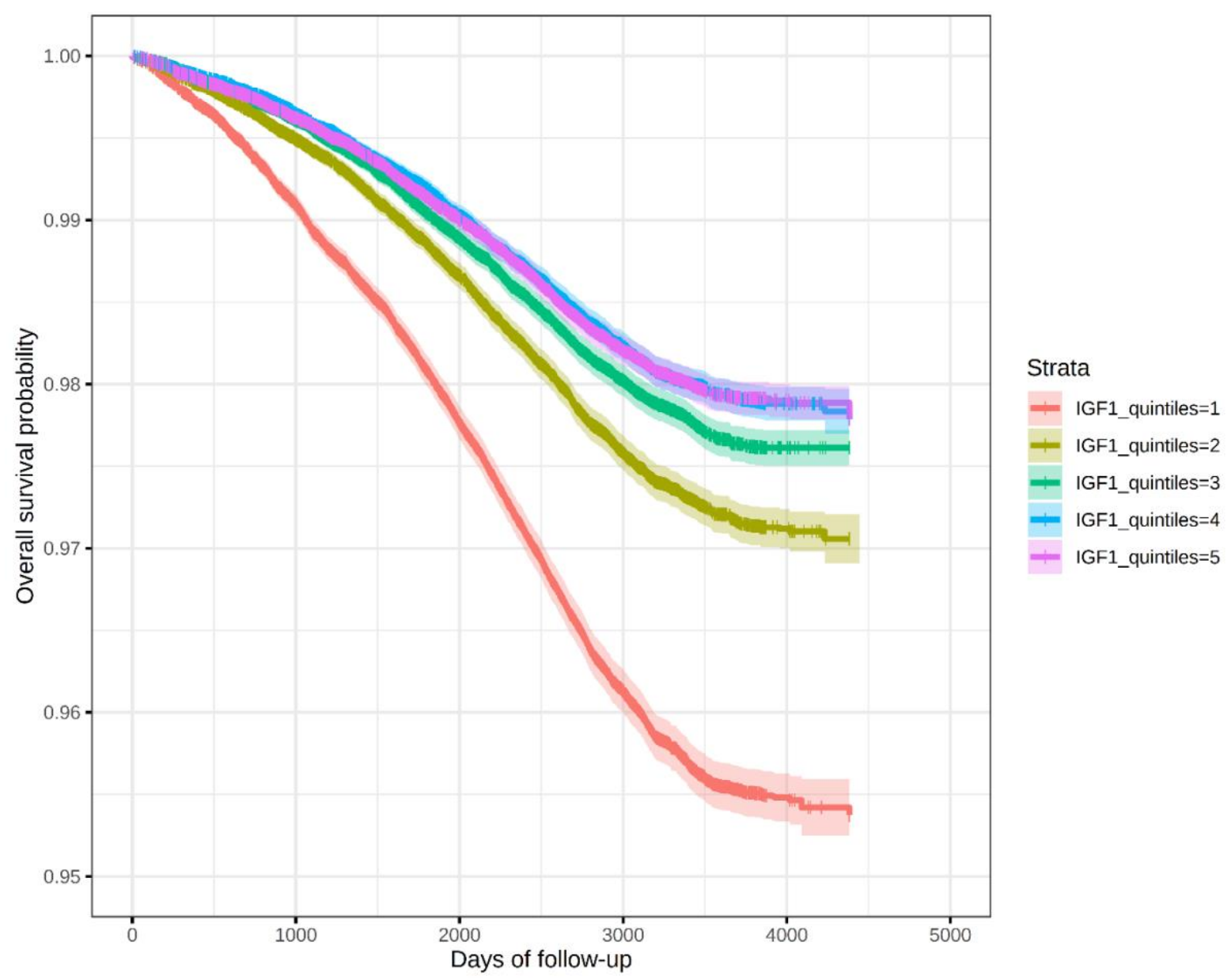

Figure 1 Kaplan Meier survival curves displaying the time to develop incident type 2 diabetes by IGF-1 quintile. The $\mathrm{x}$-axis presents days of follow-up and y-axis presents overall survival probability. Censoring is indicated by vertical marks. 


\section{MR Test}

\section{Inverse variance weighted}

Weighted median

\section{MR Egger}

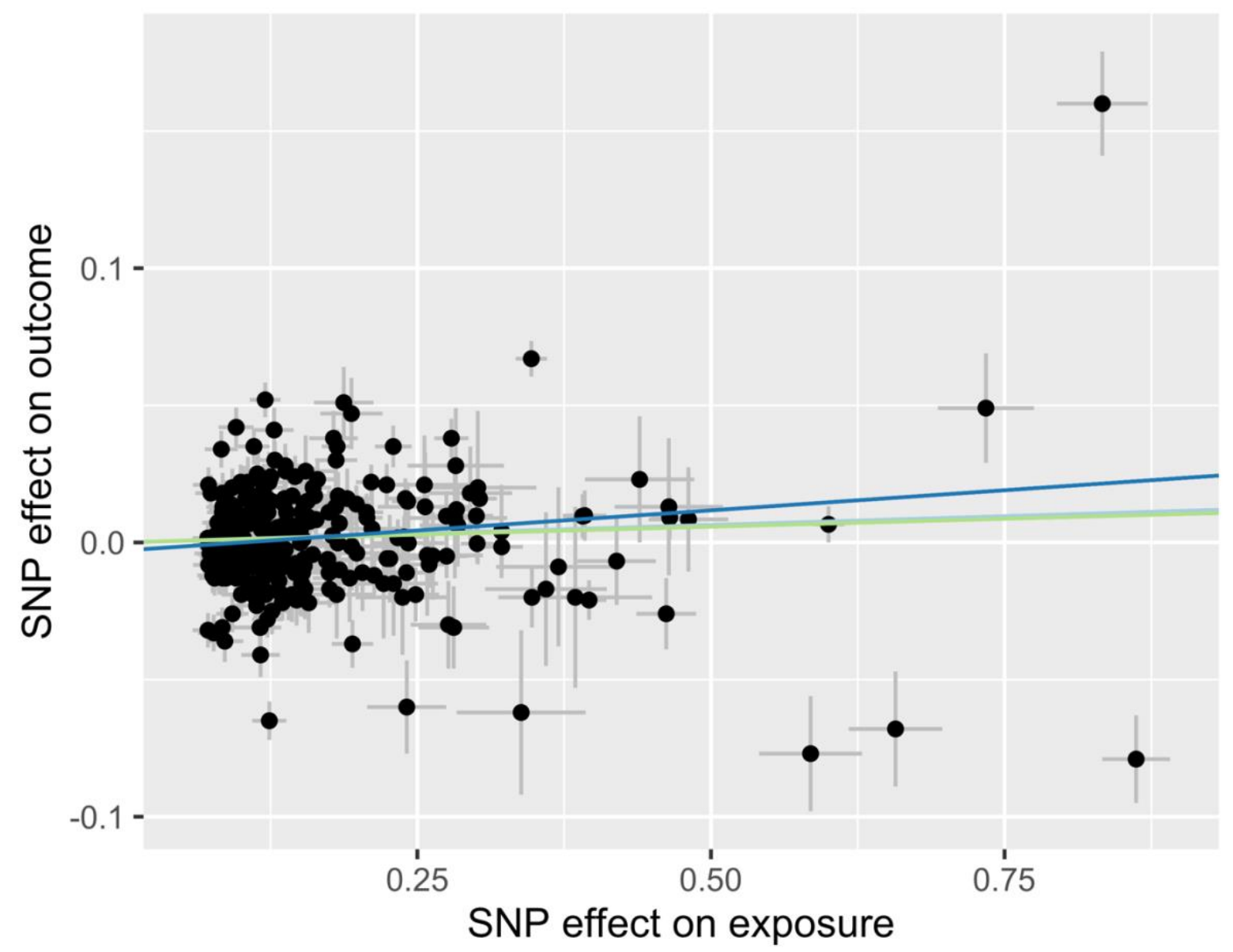

Figure 2 Scatter plots of the causal effect of continuous IGF-1 on type 2 diabetes for different MR tests. The x-axis is genetic association between SNPs and IGF-1 and the y-axis is genetic association between SNPs and type 2 diabetes. Analyses were conducted using the inverse variance weighed, weighted median and MR Egger methods. The slope of each line presents the estimated MR effect for each method. 
medRxiv preprint doi: https://doi.org/10.1101/2021.05.12.21257093; this version posted May 17, 2021. The copyright holder for this preprint (which was not certified by peer review) is the author/funder, who has granted medRxiv a license to display the preprint in perpetuity.

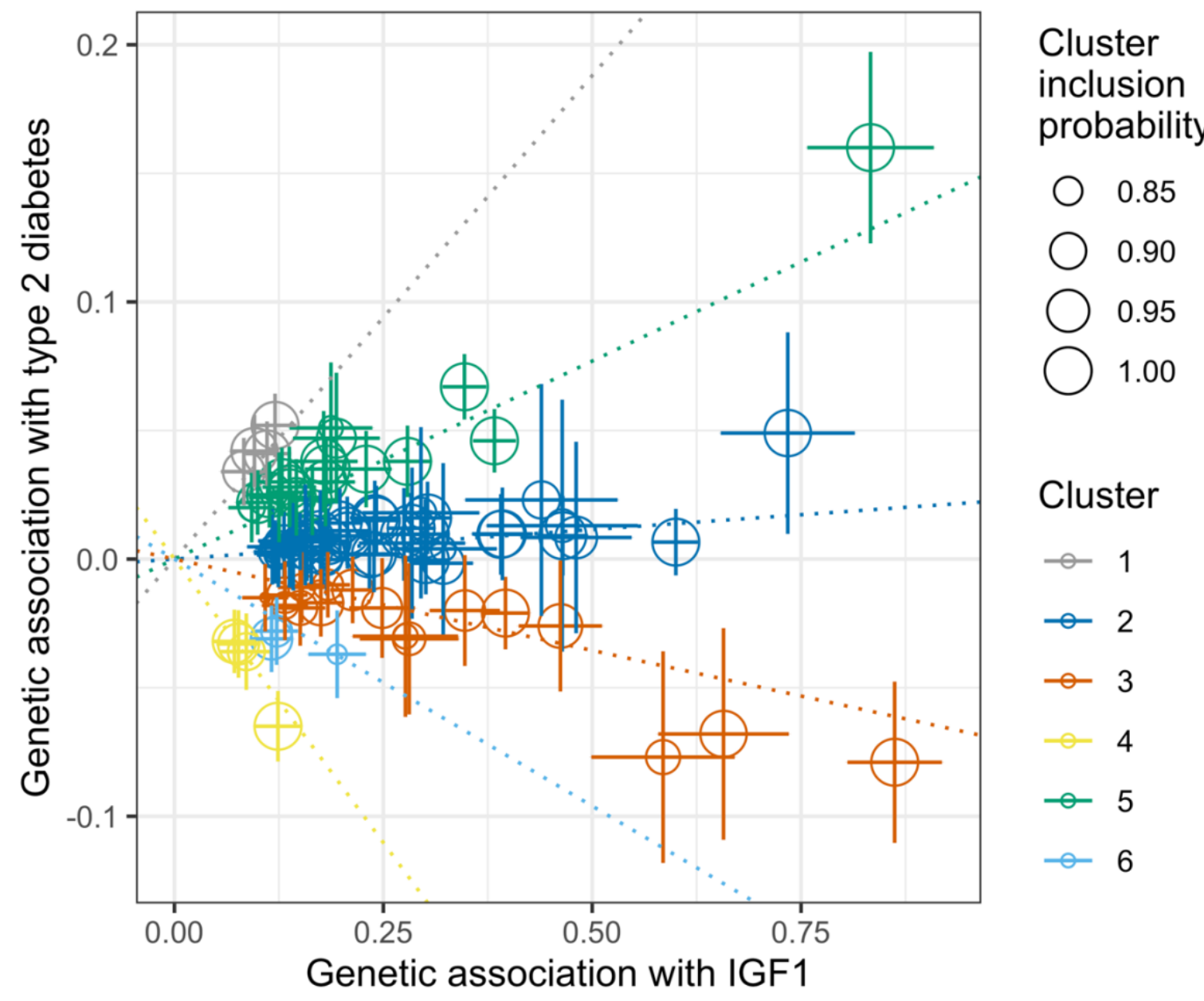

Figure 3 Scatter plots of the causal effect of continuous IGF-1 on type 2 diabetes for clustered MR analyses. The $\mathrm{x}$-axis is genetic association between SNPs and IGF-1 and the $\mathrm{y}$ axis is genetic association between SNPs and type 2 diabetes. 
medRxiv preprint doi: https://doi.org/10.1101/2021.05.12.21257093; this version posted May 17, 2021. The copyright holder for this preprint

(which was not certified by peer review) is the author/funder, who has granted medRxiv a license to display the preprint in perpetuity.

All rights reserved. No reuse allowed without permission.

Table 1 Characteristics of the UK Biobank study population for prospective analyses

\begin{tabular}{llll}
\hline & Controls & Cases & Total \\
\hline $\mathrm{N}$ & 437985 & 13247 & 451232 \\
Age at recruitment, in years & $56.5(8.1)$ & $59.3(7.2)$ & $56.6(8.0)$ \\
Time to diagnosis, in years & - & $5.3(2.5)$ & - \\
\% of women & 55.7 & 41.9 & 55.3 \\
BMI, in kg/m ${ }^{2}$ & $27.1(4.5)$ & $31.7(5.6)$ & $27.2(4.6)$ \\
IGF-1 levels in nmol/L & $21.5(5.6)$ & $19.9(6.5)$ & $21.5(5.6)$
\end{tabular}

Data presented as means with standard deviation (SD) or as stated otherwise. Information on BMI was missing for 7599 controls and 417 cases. Information on age at diagnosis was missing for 1228 cases. Information on IGF-1 levels is missing for 29889 controls and 990 cases. 
Table 2 Hazard ratio (HR) with 95\% CI of incident type 2 diabetes by IGF-1 concentration in quintiles

\begin{tabular}{llllll}
\hline & Quintile 1 & Quintile 2 & Quintile 3 & Quintile 4 & Quintile 5 \\
\hline Ranges of IGF1 (nmol/L) & $1.44-16.73$ & $16.73-19.93$ & $19.93-22.63$ & $22.63-25.77$ & $25.77-126.77$ \\
Hazard ratio (CI) & Reference & $0.77(0.73-0.81)$ & $0.70(0.66-0.74)$ & $0.68(0.64-0.72)$ & $0.76(0.72-0.81)$ \\
Hazard ratio (CI) & $1.31(1.23-1.39)$ & $1.01(0.94-1.07)$ & $0.92(0.86-0.98)$ & $0.89(0.83-0.95)$ & Reference
\end{tabular}

*This table presents the hazard ratio (HR) and 95\% confidence interval (CI) of incident type 2 diabetes by IGF-1 concentration in quintiles. The second row showed hazard ratios of incident type 2 diabetes using quintile 1 as reference group. The third row showed hazard ratios of incident type 2 diabetes using quintile 5 as reference group. 
medRxiv preprint doi: https://doi.org/10.1101/2021.05.12.21257093; this version posted May 17, 2021. The copyright holder for this preprint (which was not certified by peer review) is the author/funder, who has granted medRxiv a license to display the preprint in perpetuity. All rights reserved. No reuse allowed without permission.

Table 3 MR estimates from different methods of assessing the causal effect of 6 clusters on type 2 diabetes

\begin{tabular}{l|l|l|l|l}
\hline Clusters & \multirow{2}{*}{$\begin{array}{l}\text { Number } \\
\text { of SNPs }\end{array}$} & $\begin{array}{l}\text { Inverse variance } \\
\text { weighted }\end{array}$ & Weighted median & MR Egger \\
\cline { 3 - 5 } & OR(CI) & OR(CI) & OR(CI) \\
\hline $\begin{array}{l}\text { Cluster } \\
1\end{array}$ & 3 & $1.54(1.43-1.65)$ & $1.54(1.38-1.72)$ & $1.60(1.00-2.57)$ \\
$\begin{array}{l}\text { Cluster } \\
2\end{array}$ & 41 & $1.03(1.02-1.04)$ & $1.02(1.01-1.04)$ & $1.01(0.99-1.04)$ \\
$\begin{array}{l}\text { Cluster } \\
3\end{array}$ & 17 & $0.92(0.91-0.94)$ & $0.93(0.91-0.95)$ & $0.93(0.90-0.96)$ \\
$\begin{array}{l}\text { Cluster } \\
4\end{array}$ & 4 & $0.62(0.58-0.67)$ & $0.64(0.56-0.73)$ & $0.52(0.38-0.72)$ \\
$\begin{array}{l}\text { Cluster } \\
5\end{array}$ & 18 & $1.20(1.18-1.22)$ & $1.21(1.18-1.24)$ & $1.19(1.14-1.23)$ \\
$\begin{array}{l}\text { Cluster } \\
6\end{array}$ & 3 & $0.80(0.76-0.85)$ & $0.80(0.75-0.86)$ & $0.91(0.70-1.17)$ \\
\hline
\end{tabular}

*This table presents the odds ratio (OR) and 95\% confidence interval (CI) of causal associations between 6 clusters and type 2 diabetes 